\title{
ESPAÇO E CULTURA EM PERSPECTIVA: A PLENITUDE DA EXPERIÊNCIA GEOGRÁFICA
}

- KARINA ARROYO ${ }^{1}$

1 Doutora e Mestre em Geografia Humana pela Universidade do Estado do Rio de Janeiro (PPGEO/UERJ), geógrafa, pedagoga e socióloga. Pesquisadora do Núcleo de Estudos e Pesquisas sobre Espaço e Cultura (NEPEC/UERJ) e do Grupo de Estudos sobre Oriente Médio e Mggreb (GEOMM - PUC/MG). Atualmente é docente da British School. E-mail: kary_arc@yahoo.com.br

Recebido em:10/07/2020

Aprovado em: 22/01/2021

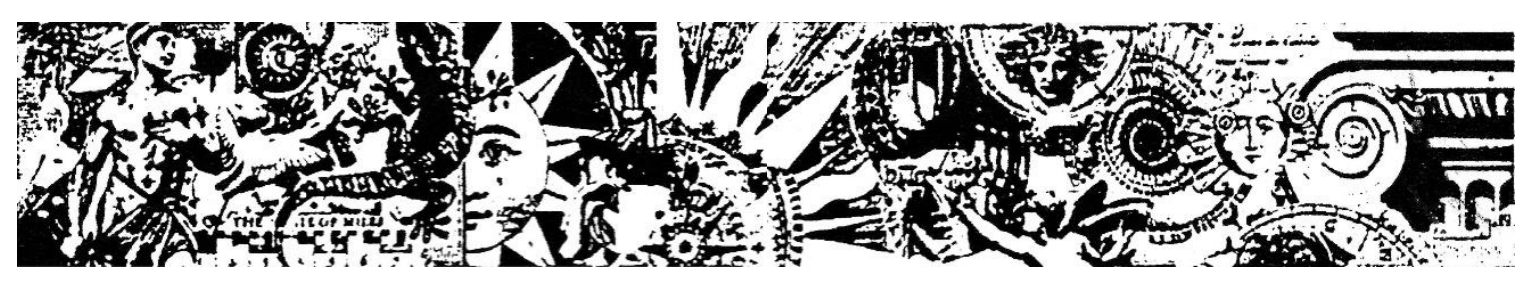

Saber pensar e produzir geografia

Um dos principais desafios que se colocam aos cientistas contemporâneos é desenvolver a capacidade de pensar cientificamente ou, sumariamente, ser capaz de carregar a curiosidade da hipótese sempre latente. Ainda assim, a investigação encontra um solo frágil se, porventura, não for capaz de agregar valores à pesquisa empreendida, indispensáveis ao sucesso e divulgação: a liberdade do pensar científico, o arremedo corajoso e consciente à pesquisa de campo e o questionamento teórico do que foi feito, até então. Só assim, se avança, se vislumbram novas perspectivas, se acede ao novo, à releitura, à ressignificação.

Essa gama de necessidades ao fazer científico só é possível se, e somente se, a rede de apoio que subsidia este novo cientista, se mostrar receptiva à novas ideias e oferecer espaço para que o novo se apresenta. Estes requisitos parecem compor uma 


\section{0:}

cartilha de admissão às novas pesquisas de um núcleo, mas não o são, já que não se encontram esses pressupostos claros e distribuídos por entre os pesquisadoresorientadores. Eu só os conheço e aprecio pois tive o privilégio de encontrá-los no Núcleo de Estudos sobre Espaço e Cultura, um grupo de pesquisa fundado em 1993 pela Dra. Zeny Rosendahl, e que por mais de 20 anos dedicou-se a difundir o arcabouço teórico da geografia cultural proveniente da Europa e que, com o passar dos anos e das pesquisas desenvolvidas, assumiu características epistemológicas relacionadas ao nosso meio.

O NEPEC, tornou-se assim, o exemplo prático do que poderia ser a epígrafe do núcleo, anteposta em qualquer artigo que referencie suas produções: "NEPEC: Lugar onde se pensam as ideias e se escreve sobre elas", frase esta que compõe o título do artigo comemorativo do núcleo (1993-2013), de autoria da fundadora e publicado na edição de número 33, em junho de 2013. O artigo destaca três importantes contribuições do NEPEC para a geografia brasileira: seu pioneirismo no desenvolvimento de estudos e pesquisas sobre a religião no espaço, seu papel de centro de divulgação da geografia cultural internacional e seu lugar de difusão da geografia cultural nacional.

$\mathrm{Na}$ acepção original do termo, o conceito de cientista carrega uma expectativa social, pois é aquele sob o qual se espera o surgimento de algo inovador, útil, que empregue o rigor metodológico, mas que não se furte a trazer a ótica humanista, do saber ver, experenciar e compreender. Sob a égide da geografia cultural, especificamente da geografia da religião, o sagrado e sua espacialidade, sua territorialidade e mesmo sua simbologia apoiam-se na vivência e na percepção do fenômeno. Como nada acontece sem estar intimamente relacionado ao espaço, a fenomenologia e seus desdobramentos teóricos encontram a possibilidade de serem agregados à filosofia metodológica de então. Caminhando nesse pensar e fazer geográfico, abrimos mais espaço para o entendimento da etnogeografia de origem francófona, apoiando-nos em Claval, grande colaborador dos estudos da geografia cultural e com sua participação ímpar, através de seus ricos artigos publicados na Revista Espaço e Cultura.

A riqueza das diferentes contribuições e perspectivas geográficas que o NEPEC recebe, desde a América Latina até a Europa, são possíveis exatamente por receber e comportar - com escrutínio, mas sem perder a generosidade da recepção de novas ideias colaborativas - essa visão ampla e acurada do que é ciência. Dentre as inúmeras visitas ao campo, ao longo da pesquisa, pude retornar com mais dúvidas do que respostas, fato este visto como positivo no caminho da construção da pesquisa. Longe de certezas e modelos, mas perto de possibilidades e percepções, o NEPEC abriga uma pluralidade 
temática de grande impacto ao vislumbrarmos toda a produção publicada em periódicos na área de geografia e, também, na área das ciências humanas, em geral. Os estudos publicados não são cristalizados no tempo-espaço como monolíticos conceituais.

Há uma constante e intensa releitura, discussão conceitual e importantes avanços a cada biênio, períodos nos quais se organizam os Simpósios Internacionais sobre Espaço e Cultura. Naqueles momentos de celebração, os estudos são revisitados, debatidos, novas ideias surgem e um horizonte infinito de possibilidades se configura com um potencial inequívoco para os próximos geógrafos que se comprometem a um fazer geográfico humanista, científico, altruísta e responsável. Os dois anos seguintes, até o próximo reencontro, são esperados por toda a comunidade geográfica, nacional e internacional, na certeza de que suas hipóteses inspiradas por aquele encontro anterior, terão novos desdobramentos ou reformulações.

A investigação empreendida por mim - o longo dos seis anos que estive no NEPEC - procurou compreender como o Sagrado se manifesta em seu território religioso e justificou a necessidade de uma releitura sobre o conceito considerando o meu objeto de pesquisa, carregado de simbolismo por ter íntima relação com uma Terra Imaginalis islâmica, A partir disso, analisou-se e desenvolveu-se o resultado desta releitura, o território matriz.

Nota-se que este grande passo conceitual ocorreu devido a alguns fatores que, em muito, favoreceram meu processo investigativo: a) a ampla bibliografia disponível no NEPEC para consulta e empréstimo; b) a orientação acadêmico-científica da fundadora e orientadora - Dra. Zeny Rosendahl - que concede aos investigadores sob sua tutela, a total possibilidade de expressão das suas ideias para posterior análise de adequação e correspondência cientifica; c) a representatividade, participação e menção ao NEPEC na maioria dos eventos da geografia cultural no país e no exterior; d) a publicação da Revista Espaço e Cultura e sua consolidação como veículo de promoção e atualização da geografia cultural e da geografia da religião no país e no exterior; e) a cultura da colaboração e da participação ativa de investigadores estrangeiros, não só na produção escrita mas no intercâmbio constante de ideias, eventos e projetos, garantindo a internacionalização da produção nepeciana; f) o incentivo para a produção e publicação de artigos em regime de co-autoria ou autoria solo em periódicos da área, para solidificar o caminhar investigativo e g) a atual coordenação do NEPEC, há alguns anos conferida à Dra. Mariana Lamego, que conduz com os mesmos valores, brilhantismo e dedicação o legado primoroso anteriormente lhe passado. 
Julgo pertinente ressaltar que o sucesso de um Núcleo da monta do NEPEC não se deve somente ao incansável trabalho acadêmico-científico, constante e contumaz ao longo das décadas, muito embora, este seja um fator primordial. Há um substrato afetivo que não se pode desconsiderar neste depoimento.

O NEPEC é a materialização ou o exemplo máximo do conceito tuanino do que seja o lar-lugar. Lugar pressupõe afeto, sentir-se pertencente a um determinado ambiente. Ele reproduz uma cosmologia familiar conferindo-lhe a sensação de lar familiar, de confiança e respeito mútuo. Poder-se-ia dizer que o NEPEC, para os que ali têm o privilégio de aprender, é o centro do mundo, o referencial do saber, do amadurecimento intelectual e da libertação plena. O indivíduo que ali ingressa, desenvolve a independência reflexiva, a faculdade da razão em sua plenitude. Não há um cientista, não há um geógrafo cultural se, no seu interior, não se vislumbrar para além da potência investigativa a autonomia intelectual e a criticidade de ver e experenciar os fenômenos do mundo. Vida longa ao NEPEC! 